\title{
Recent Changes in Arctic Sea Ice: The Interplay between Ice Dynamics and Thermodynamics
}

\author{
Jinlun Zhang, Drew Rothrock, AND Michael Steele \\ Polar Science Center, Applied Physics Laboratory, College of Ocean and Fishery Sciences, University of Washington, \\ Seattle, Washington
}

(Manuscript received 28 December 1998, in final form 22 November 1999)

\section{ABSTRACT}

\begin{abstract}
It is well established that periods of high North Atlantic oscillation (NAO) index are characterized by a weakening of the surface high pressure and surface anticyclone in the Beaufort Sea and the intensification of the cyclonic circulation in the eastern Arctic Ocean. The response of Arctic sea ice to these atmospheric changes has been studied with a thickness distribution sea-ice model coupled to an ocean model. During a period of high NAO, 1989-96, the model shows a substantial reduction of ice advection into the eastern Arctic from the Canada Basin, and an increase of ice export through Fram Strait, both of which tend to deplete thick ice in the eastern Arctic Ocean and enhance it in the western Arctic, in an uneven dipolar pattern we call the East-West Arctic Anomaly Pattern (EWAAP). From the period 1979-88 with a lower-NAO index to the period 1988-96 with a high-NAO index, the simulated ice volume in the eastern Arctic drops by about a quarter, while that in the western Arctic increases by 16\%. Overall, the Arctic Ocean loses 6\%. The change from 1987 to 1996 is even larger-a loss of some $20 \%$ in ice volume for the whole Arctic. Both the model and satellite data show a significant reduction in ice extent in the eastern Arctic and in the Arctic Ocean as a whole.

There are corresponding changes in open water and therefore in ice growth, which tend to moderate the anomaly, and in lateral melting, which tends to enhance the anomaly. During the high NAO and strong EWAAP period, 1989-96, the eastern (western) Arctic has more (less) open water and enhanced (reduced) winter ice growth, so ice growth stabilizes the ice cover. On the other hand, the increased (decreased) open water enhances (reduces) summer melt by lowering (increasing) albedo in the eastern (western) Arctic. The nonlinearity of icealbedo feedback causes the increased summer melt in the eastern Arctic to dominate the thermodynamic response and to collaborate with the ice advection pattern to enhance the EWAAP during high NAO.
\end{abstract}

\section{Introduction}

Significant changes in the Arctic climate have been detected in the late 1980s and 1990s. During that period, there has been a substantial decrease in sea level pressure in the Arctic, characterized by a weakening of the Beaufort high pressure cell and a strengthening of the European subarctic low pressure cell and thus an altered wind circulation pattern (Walsh et al. 1996). This atmospheric state is described as a positive phase of the North Atlantic oscillation (NAO; Hurrell 1995) and of the larger-scale Arctic oscillation (AO; Thompson and Wallace 1998). Meanwhile, recent scientific cruises aboard submarines and ice breakers provide synopticlike hydrographic data that reveal large-scale changes in the Arctic Ocean in the 1990s owing to an increased influence of Atlantic water. This influence is manifested by a noticeable and persistent increase in temperature

Corresponding author address: Dr. Jinlun Zhang, Applied Physics Laboratory, University of Washington, 1013 NE 40th Street, Seattle, WA 98105-6698.

E-mail: zhang@apl.washington.edu and salinity over a large area within various layers of the upper ocean in the Arctic (Carmack et al. 1995; McLaughlin et al. 1996; Morison et al. 1998; Steele and Boyd 1998). A model study by Zhang et al. (1998a) also reveals a significant warming and salinification in the upper ocean of the Arctic owing to a sustained increase in the inflow of warm and salty Atlantic water both at Fram Strait and, most significantly, via the Barents Sea.

Moreover, based on recent satellite data, U.S. Navy/ National Oceanic and Atmospheric Administration (NOAA) National Ice Center charts and regional data sources (Gloersen and Campbell 1991; Chapman and Walsh 1993; Johannessen et al. 1995; Cavalieri et al. 1997), and model results (e.g., Zhang et al. 1998a), there has been a noticeable downward trend in the extent of Arctic sea ice. Although it is too early to conclude that the trend is permanent, it is inevitably linked with the changes in the dynamics and thermodynamics of the atmosphere and the ocean in the Arctic. To obtain insight into how the sea-ice cover responds to the climate changes in the Arctic in the late 1980s and 1990s, we investigate the behavior of the ice cover during the pe- 
riod 1979-96 that includes the Arctic climate changes described above.

We carried out this study with a multicategory thickness distribution sea-ice model and coupled that model with an ocean model with an embedded mixed layer. The model domain covers the Arctic, Barents, and Greenland-Iceland-Norwegian (GIN) Seas. The mixedlayer-ocean model is based on Zhang (1993) and Zhang et al. (1998b). The thickness distribution sea-ice model, based on Flato and Hibler (1995) and Zhang and Hibler (1997), simulates the ridging process, calculates thermodynamic growth and decay over each thickness category, and therefore captures the essence of the coupling of the dynamic and thermodynamic sea ice processes. The model components are described more fully in section 2. Section 3 describes the variations in winds and surface air temperatures that have occurred over the last two decades. Section 4 describes how the ice motion and mass fields react to these atmospheric changes. In section 5 , we review the results in a climate change context.

\section{Model description}

The coupled model consists of two components: a thickness distribution sea-ice model (Hibler 1980; Flato and Hibler 1995; Zhang and Hibler 1997) and an ocean model embedded with a mixed layer (Zhang 1993; Hibler and Zhang 1993; Zhang et al. 1998b). Both models are coupled in such a way that heat, mass, and momentum are conserved. The sea-ice model supplies surface heat, salt, and momentum fluxes into the ocean as ocean surface boundary conditions. The ocean model, in turn, aided by the mixed-layer model, supplies surface current and heat exchange information to the ice model. The mixed-layer model, driven by the surface fluxes, monitors the evolution of the mixed layer and modifies the temperature and salinity structure of the upper ocean. Some aspects of the models are described in the following sections.

\section{a. Sea-ice model}

The sea-ice model consists of three main components: a momentum equation that determines ice motion, a viscous-plastic ice rheology with an elliptical yield curve that determines the relationship between ice internal stress and ice deformation and strength, and ice thickness distribution equations that determine the evolution of ice thickness. The first two components are described in detail by Hibler (1979) and Zhang and Hibler (1997) for a two-category dynamic-thermodynamic sea-ice model. In this coupled model, the ice momentum equation is solved using Zhang and Hibler's (1997) numerical model for ice dynamics. The ice thickness distribution equations are described in detail by Flato and Hibler (1995). There are two conservation equations for thickness distributions of ridged ice and undeformed ice, respectively, which are written as

$$
\begin{aligned}
& \frac{\partial g_{r}}{\partial t}=-\boldsymbol{\nabla} \cdot\left(\mathbf{u} g_{r}\right)-\frac{\partial\left(f_{r} g_{r}\right)}{\partial h}+\psi_{r}+F_{r} \quad \text { and } \\
& \frac{\partial g_{u}}{\partial t}=-\boldsymbol{\nabla} \cdot\left(\mathbf{u} g_{u}\right)-\frac{\partial\left(f_{u} g_{u}\right)}{\partial h}+\psi_{u}+F_{u},
\end{aligned}
$$

where the subscript $r$ refers to ridged ice, the subscript $u$ refers to undeformed ice, $g_{r}(h)$ and $g_{u}(h)$ are the ridged and undeformed ice thickness distributions; respectively, $\mathbf{u}$ is ice velocity, $f_{r}$ and $f_{u}$ are ice growth rates, $\psi_{r}$ and $\psi_{u}$ are redistribution functions, or source terms that describe the change in thickness distribution due to ridging, and $F_{r}$ and $F_{u}$ are called source terms of lateral melting by Flato and Hibler (1995). Although (1) and (2) are solved separately, they can be combined into one equation for analyzing model results, such that

$$
\frac{\partial g}{\partial t}=-\boldsymbol{\nabla} \cdot(\mathbf{u} g)-\frac{\partial(f g)}{\partial h}+\psi+F_{L},
$$

where $g(h)=g_{r}(h)+g_{u}(h)$ is defined here as total ice thickness distribution that is a normalized probability density function, $f(h)=f_{r}(h)=f_{u}(h)$ is ice growth rate, $\psi=\psi_{r}+\psi_{u}$ is the total redistribution function due to ridging, and $F_{L}=F_{r}+F_{u}$ is the total source term for lateral melting. Note that $F_{L}$ is actually the combined oceanic heat flux that enters the mixed layer from the deep ocean and a portion of the surface heat flux that enters the mixed layer through leads. This absorbed heat in the mixed layer does not participate in determining $f(h)$ but is allocated to melting ice through $F_{L}$ (Hibler 1980). The reason $F_{L}$ is called lateral melting term is because it was formulated by Hibler (1980) to reduce all thickness categories in proportion to their abundance based on the physical notion that thicker ice will have a larger vertical interface with the ocean than thinner ice. The first term on the right-hand side of (3) describes the change in thickness distribution due to ice advection; the second term on the right-hand side of (3) describes the change in thickness distribution due to ice growth (ice melt when $f<0$ ). In essence, (3) states that a change in ice thickness distribution is due to a combination of ice advection, ice growth, ridging, and lateral melting.

Accompanying the ice model is a snow model described in terms of snow thickness distribution, $g_{s}(h)$, corresponding to the total ice thickness distribution, $g(h)$. The snow conservation equation, the treatment of the snow thickness distribution, and the treatment of the thermodynamics at the ice-snow-ocean surface, including surface albedo, are determined by Flato and Hibler (1995, appendix). All the snow and ice thermodynamic parameters used here are the same as those used in the standard case of Flato and Hibler (1995). 


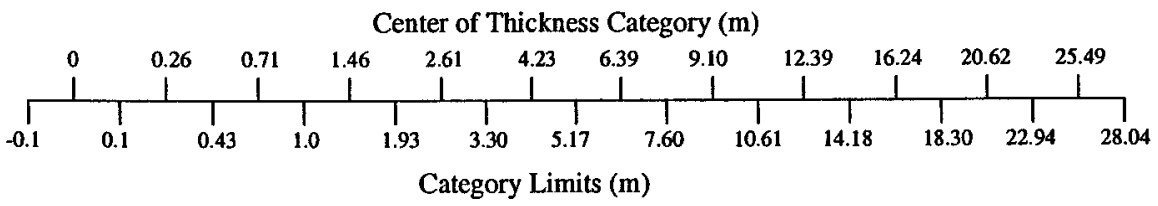

FIG. 1. Schematic arrangement of thickness partition used in the ice-ocean model.

\section{b. Mixed-layer-ocean model}

A detailed description of the coupled mixed-layerocean model is given by Zhang (1993) and Zhang et al. (1998b). Briefly, the ocean model is based on the BryanCox model (Bryan 1969; Cox 1984; also see Semtner 1986). The ocean temperature and salinity below the mixed layer are constrained to the Levitus (1982) climatological values with a weak restoring constant of 5 yr, which Zhang et al. (1998b) found gave the best results of several restoring options. The mixed-layer model is based on that of Kraus and Turner (1967) (see also Niiler and Kraus 1977). It is coupled into the ocean model in such a way that the heat, salt, and potential energy are conserved (see Zhang 1993).

\section{c. Numerical framework}

Some basic numerical features are mentioned here. More information about finite differencing and time

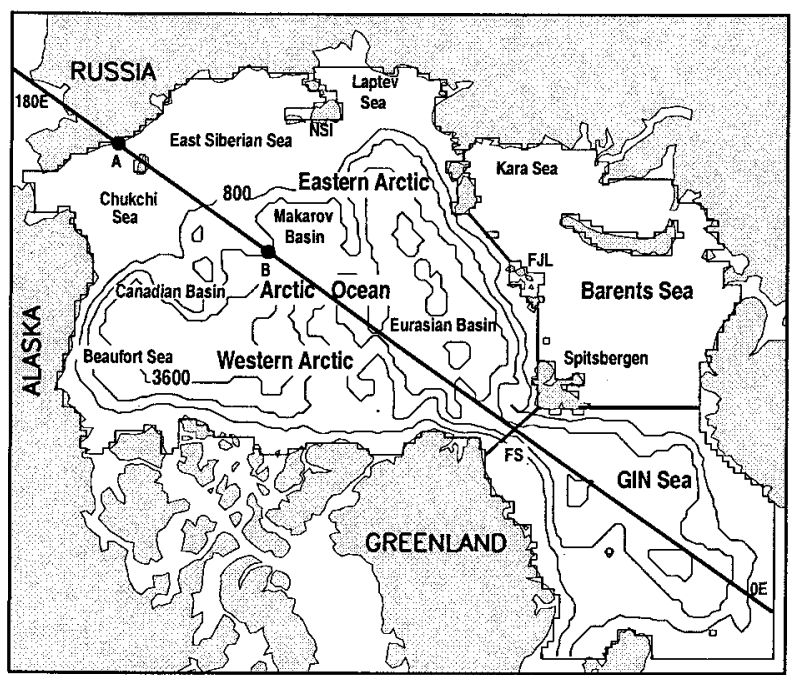

FIG. 2. Model domain and bathymetry. Contour interval is 1400 $\mathrm{m}$. The model domain is divided by thick black lines into three geographic areas: the Arctic Ocean, the Barents Sea, and the GIN (Greenland-Iceland-Norwegian) Sea. For analyses of results, the Arctic is further divided by the prime meridian $\left(0^{\circ}-180^{\circ} \mathrm{E}\right)$ into two regions: the eastern Arctic and the western Arctic. The open boundaries of the eastern Arctic are along the prime meridian, eastern Fram Strait, and the openings between Spitzbergen and Russia. Those of the western Arctic are along the prime meridian, western Fram Strait, and the Bering Strait. Ice advection is analyzed across the transect between $\mathrm{A}$ and $\mathrm{B}(\overline{\mathrm{AB}})$ along the prime meridian in the Chukchi Sea and Canadian Basin. Fram Strait, Franz Josef Land, and New Siberian Island are marked as FS, FJL, and NSI. stepping is given by Zhang et al. (1998a). The model has a horizontal resolution of $40 \mathrm{~km} \times 40 \mathrm{~km}$, with 21 ocean levels of different thicknesses, 12 ice thickness categories each for ridged ice and undeformed ice, and 12 snow thickness categories corresponding to the 12 ice thickness categories. The 12 ice thickness categories (Fig. 1) are partitioned following a Gaussian distribution (Hibler 1980) to obtain a thickness mesh smoothly varying in spacing. The model domain and bottom topography are shown in Fig. 2.

\section{d. Surface atmospheric forcing}

The coupled ice-mixed-layer-ocean model is driven by surface atmospheric forcing during 1979-96. The forcing consists of geostrophic winds, surface air temperature, specific humidity, and longwave and shortwave radiative fluxes (the forcing can be downloaded from http://psc.apl.washington.edu/POLES/ model_forcings/ModelForcings.html on the Internet). The geostrophic winds are calculated using gridded, twice-daily, sea level pressure (SLP) fields provided by I. G. Rigor from the International Arctic Buoy Program (IABP) (see Thorndike et al. 1983). The twice-daily $2-\mathrm{m}$ surface air temperature data are derived from buoys, manned drifting stations, and all available land stations (Rigor et al. 2000; also see Martin and Munoz 1997). The specific humidity and longwave and shortwave radiative fluxes are calculated following the method of Parkinson and Washington (1979) based on the SLP and air temperature fields. Model input also includes river runoff and precipitation. The climatological river runoff is the same as that specified by Hibler and Bryan (1987), while the monthly varying region-dependent precipitation is from the Vowinckel and Orvig (1970) climate description. Neither river runoff nor precipitation contains any interannual variability.

\section{Recent changes in atmospheric forcing}

In order to explain better the model's response to the recent climate changes in the Arctic, it is helpful to show how the changes are reflected in the surface atmospheric forcing that is used to drive the model. According to Walsh et al. (1996), a possible "phase" change in the Arctic climate appeared to occur after 1987, and there is a sharp drop in the annual mean SLP in 1988 (Fig. 3a). In 1989, the SLP falls further, to the lowest of the $18 \mathrm{yr}$ under consideration. After that, the mean SLP 


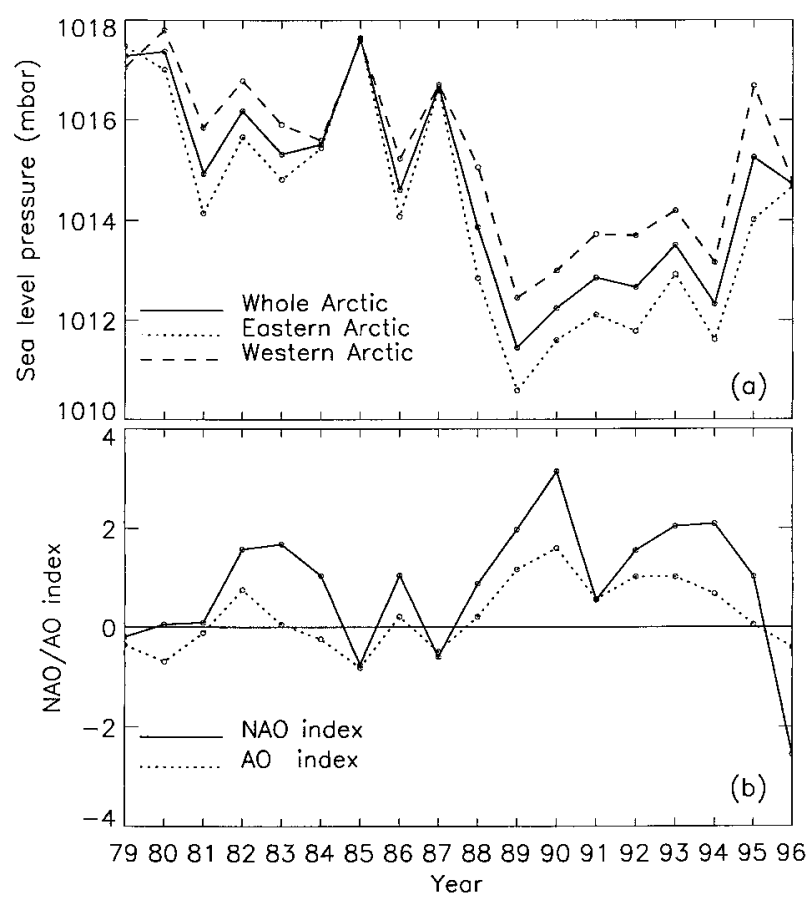

FIG. 3. (a) Annual mean sea level pressure for 1979-96 over the eastern, western, and whole Arctic. (b) The NAO and AO indices from Hurrell (1995) and Thompson and Wallace (1998), respectively.

generally stays low through 1994. This is true in both the eastern and western Arctic. The change in SLP is closely related to the NAO (Hurrell 1995) and, in a broader scaler, to the AO (Thompson and Wallace 1998), which have relatively high indexes in recent years (Fig. $3 b)$.

The changes in SLP in the late 1980s and 1990s are further illustrated in Fig. 4, which compares SLP fields averaged over 1979-88 and 1989-96. The changes are pronounced. The basic feature of the Arctic SLP is the Beaufort Sea anticyclone. Away from the gyre's center, toward the European subarctic (Norwegian, Barents, and Kara Seas), the SLP decreases. This European subarctic low is often linked to the Icelandic low and associated with cyclonic systems that track from the North Atlantic into the Arctic (Walsh et al. 1996; Serreze et al. 1993). As shown in Fig. 4, the location, shape, and intensity of the Beaufort high are considerably different in 1989-96 than in 1979-88. In 1979-88, the Beaufort high is strong and covers almost all of the Arctic; in 1989-96, the Beaufort high weakens and shrinks toward the Alaskan coast, while the European subarctic low strengthens and advances toward the central Arctic.

The importance of SLP is that the SLP gradient determines the geostrophic winds that drive the sea ice and are largely responsible for sea-ice motion. The correlation between geostrophic winds and ice motion can be as high as 0.8 in the central Arctic (Thorndike and Colony 1982; Serreze et al. 1989; Steele et al. 1997; Thomas 1999). Vector plots of the mean fields of geo- strophic winds for 1979-88 and 1989-96 are included in Fig. 4. These plots show pronounced changes in 1989-96 corresponding to the changes in SLP. The mean wind field of 1979-88 is stronger than that of 198996, so the 1979-88 anomaly field (Fig. 4c) is cyclonic, whereas the 1989-96 anomaly field (Fig. 4d) is anticyclonic. Also, the northerly winds at Fram Strait are stronger in recent years because the SLP contours there tend to be more parallel to the northeast coast of Greenland.

The annual mean surface air temperatures are plotted in Fig. 5, which show much interannual variability over the $18 \mathrm{yr}$ (Rigor et al. 2000). The difference between the highest temperature and the lowest one for the whole Arctic is more than $3^{\circ} \mathrm{C}$. The temperature decreases from 1981 to 1987 , with the Arctic being the coldest in 1987. After 1987, the temperature generally increases. In the eastern Arctic, the temperature is up $1{ }^{\circ} \mathrm{C}$ in 1989-96 compared to 1979-88, while in the western Arctic it is up $0.4^{\circ} \mathrm{C}$. Accordingly, the average temperature over the whole Arctic is up $0.7^{\circ} \mathrm{C}$ in $1989-96$, compared to its 1979-96 mean.

\section{Model results and observations}

The model was integrated over two 18-yr cycles driven by forcing fields from 1979 to 1996 . The evolution of the ice cover is stabilized approximately after one cycle of integration. The ocean also reaches a nearequilibrium state because of the climate restoring of ocean temperature and salinity below the mixed layer (see Zhang et al. 1998b). The results presented here are based on the second cycle. Given that changes in the Arctic climate have occurred since 1988, we focus on the behavior of the ice cover in 1989-96. We compare the model results and observations over that period with those over 1979-88. We also compare model results and observations between the eastern and western Arctic because the ice cover, driven by a varying wind circulation, behaves differently in the two regions.

\section{a. Recent changes in ice motion: Beaufort gyre and Fram Strait outflow}

Figure 6 shows simulated mean ice velocity fields in the Arctic for 1979-88 and 1989-96 and the corresponding anomaly fields. The most notable feature of the simulated ice motion is a consistent anticyclonic Beaufort gyre and a transpolar drift stream, both in 1979-88, when the Beaufort high was strong, and in 1989-96, when it was weak. However, in response to the recent changes in atmospheric circulation (Fig. 4), the shape and intensity of the anticyclone and the transpolar drift in 1989-96 are different from those in 197988. In 1979-88, the wind gyre (Fig. 4) covers most of the Arctic, and so does a robust Beaufort ice gyre. In 1989-96, the Beaufort high weakens and retreats toward the Alaskan coast; as a result, the ice gyre is less robust 


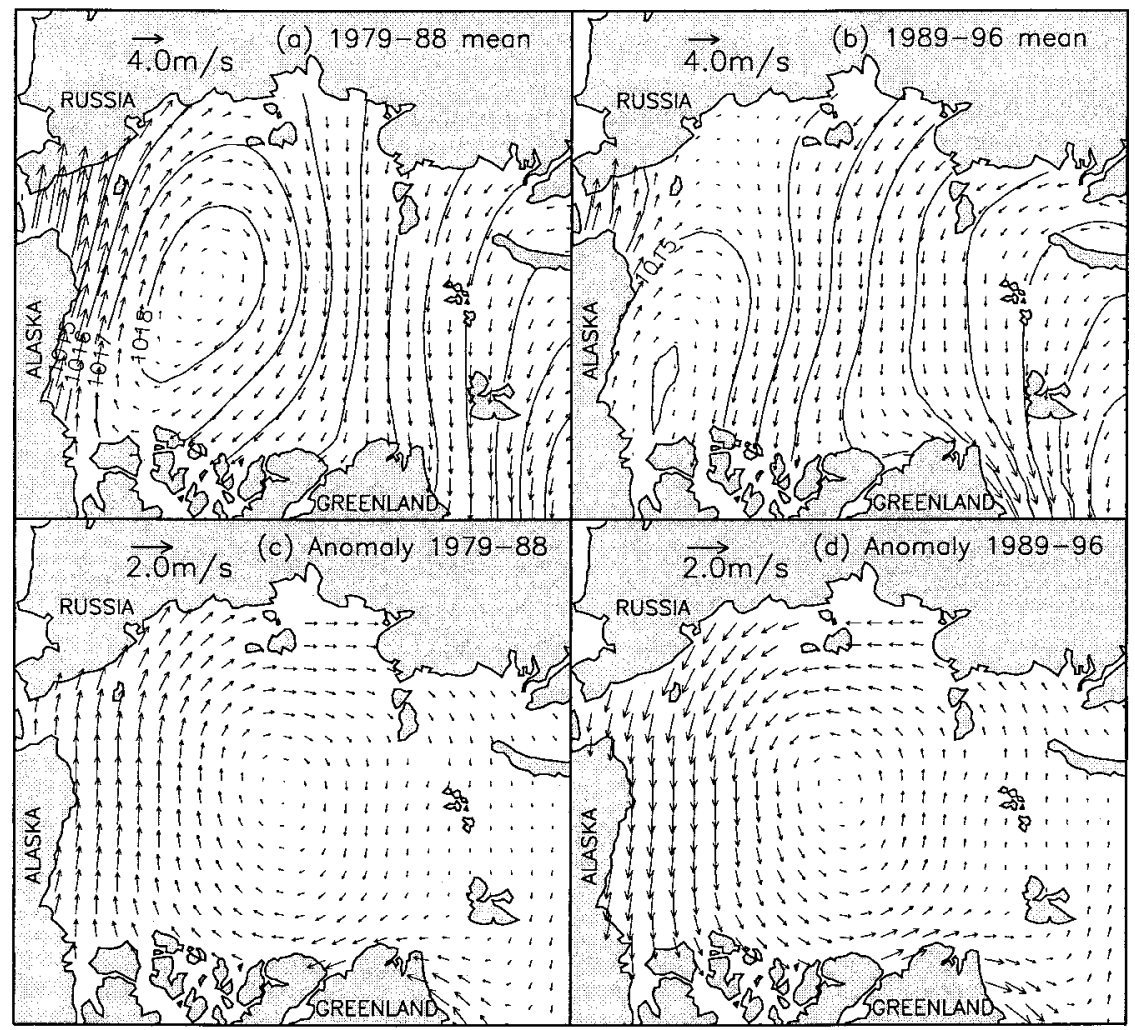

FIG. 4. Mean geostrophic wind velocity $\left(\mathrm{m} \mathrm{s}^{-1}\right)$ fields and annual mean sea level pressure contours for (a) 1979-88 and (b) 1989-96; anomaly fields of geostrophic wind velocity based on the differences (c) between the 1979-88 mean and the 1979-96 mean and (d) between the 198996 mean and the 1979-96 mean. The vectors are drawn at every sixteenth grid point and the contour interval is 1.0 mbar.

and more centered in the Beaufort Sea and Canadian Basin. Also, ice outflow at Fram Strait appears to be stronger in 1989-96 because of stronger northerly winds.

Perhaps the recent changes in ice motion can be better

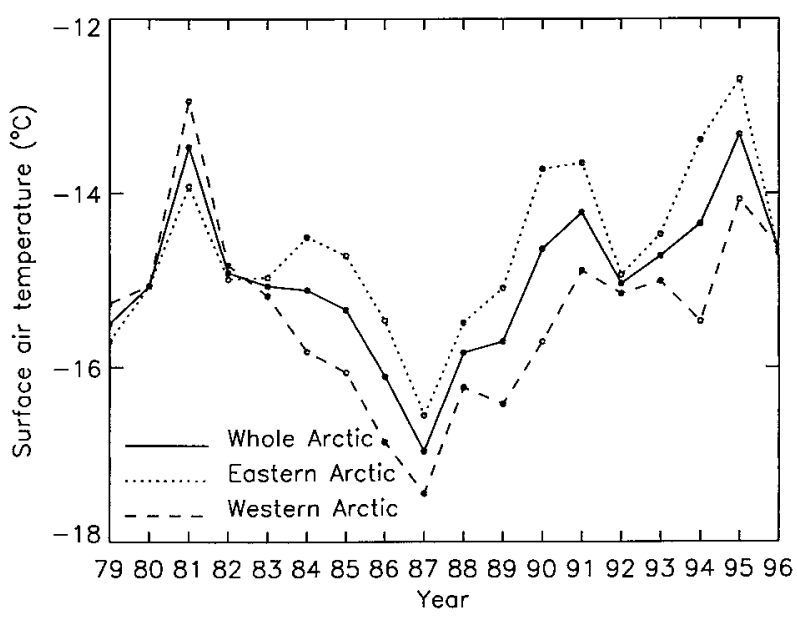

FIG. 5. Annual mean surface air temperature averaged over the eastern, western, and whole Arctic. illustrated by the anomaly fields of ice motion shown in Figs. $6 \mathrm{c}$ and $6 \mathrm{~d}$. The anomaly fields closely resemble the wind anomaly fields (Fig. 4c and 4d) except in some areas along the coast of the Arctic Basin, where internal interaction of the ice appears to have a greater effect on ice motion and generally reduces ice speed along lateral boundaries. When there is a strong Beaufort high, as in 1979-88, there is generally a strong anticyclonic ice motion anomaly in the Arctic. When the Beaufort high weakens and the European subarctic low advances toward the central Arctic, as in 1989-96, the ice motion anomaly is cyclonic. Also illustrated by the anomaly fields is the recent intensification of anomalous ice outflow in the Fram Strait area.

The intensification of ice areal and volume outflows at Fram Strait is shown in Fig. 7. The simulated areal outflow by the model is significantly larger in 1989-96 than in 1979-88, whereas the estimated areal outflow by Kwok and Rothrock (1999) based on satellite data is larger to a lesser degree in 1989-96 than in 197988. On average, both are close to the value of $0.9 \times$ $10^{12} \mathrm{~m}^{2} \mathrm{yr}^{-1}$ estimated by Colony (1990) based on buoy observations. Because of the intensified ice areal outflow, the annual volume outflow at Fram Strait is mostly 


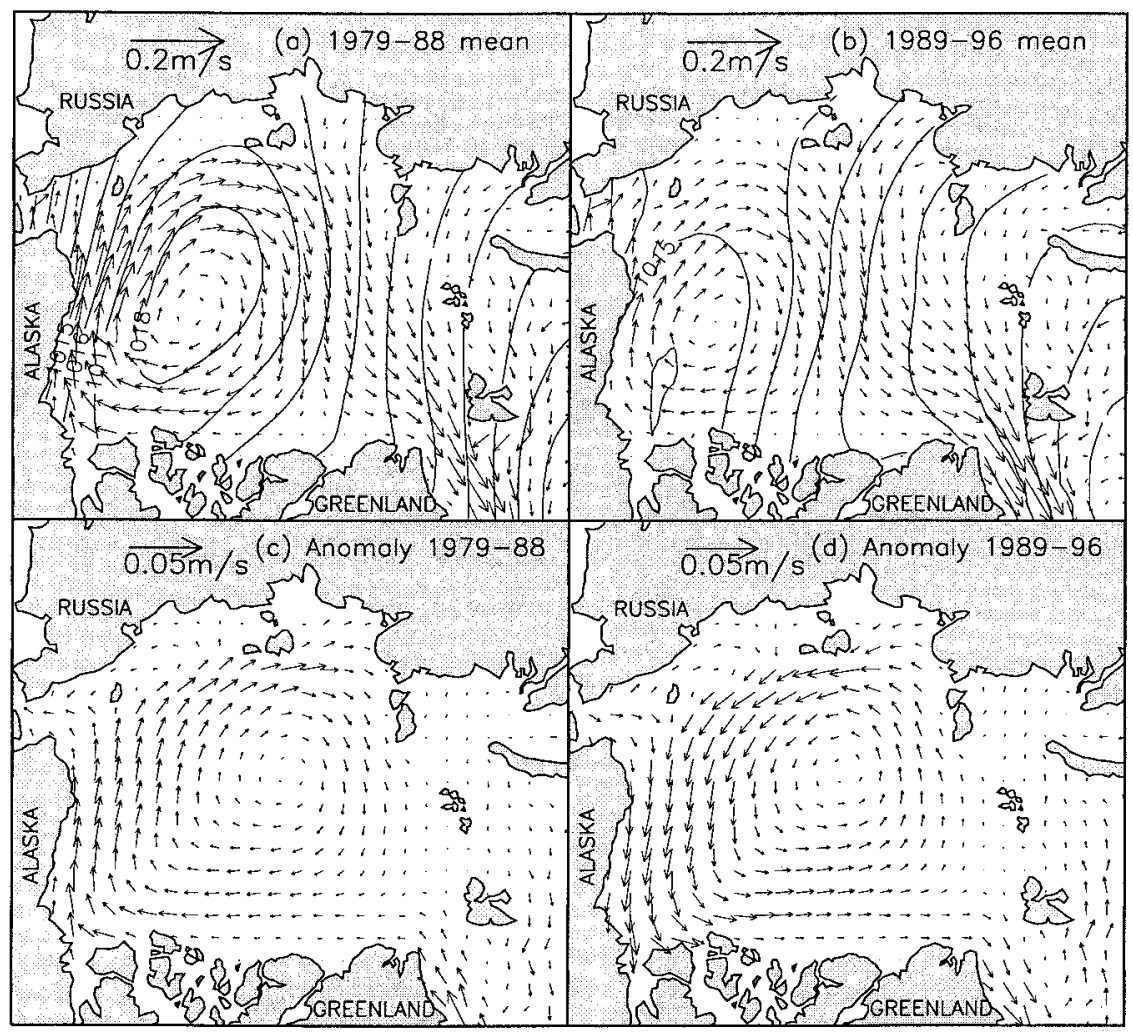

FIG. 6. Simulated mean ice velocity $\left(\mathrm{m} \mathrm{s}^{-1}\right)$ fields and annual mean sea level pressure contours for (a) 1979-88 and (b) 1989-96; anomaly fields of ice velocity based on the differences (c) between the 1979-88 mean and the 1979-96 mean and (d) between the 1989-96 mean and the 1979-96 mean. The vectors are drawn at every sixteenth grid point and the contour interval is 1.0 mbar.

above or at the average during 1989-96 (Fig. 7b). The average ice volume outflow at Fram Strait is $3.7 \times 10^{12}$ $\mathrm{m}^{3} \mathrm{yr}^{-1}$ in 1989-96, up $0.7 \times 10^{12} \mathrm{~m}^{3} \mathrm{yr}^{-1}$ from 1979 to 1988 (Table 1). Also shown in Fig. $7 \mathrm{~b}$ are Harder et al.'s (1998) results, which are generally smaller than ours. Note that both Harder et al.'s model and input forcing are different from ours.

\section{b. Recent changes in ice concentration: Eastern versus western Arctic}

The satellite-observed and the model-simulated fields of ice concentration for 1979-88 and 1989-96 are compared in Fig. 8. Here, the simulated ice concentration is defined as $1-G_{1}$, where $G_{1}$ is the fraction of area taken by the open-water category, that is, the first ice thickness category illustrated in Fig. 1. Strictly speaking, the simulated concentration is not defined in the same way as the observed one, which is derived from brightness temperature. Nevertheless, it is still possible to make comparisons in a relative sense. For example, it is not hard to tell that the model underestimates ice concentration in the Beaufort Sea and, particularly, in the area off the Alaskan coast in 1979-88. In 1989-96, the model underestimates ice concentration in the east- ern Arctic and overestimates ice concentration in the area off the Alaskan coast. Otherwise, the simulated concentration is in general agreement with the observed concentration.

Perhaps the changes in Arctic ice concentration are better illustrated by the difference fields, also included in Fig. 8. The difference field for the satellite observations (Fig. 8e) shows a somewhat dipolar pattern; ice concentration decreases in recent years in most of the eastern Arctic (see also Maslanik et al. 1996; Serreze et al. 1995), except in the Kara Sea, a limited area near New Siberian Island in the Laptev Sea, and the area between Spitzbergen and Franz Josef Land. In the meantime, ice concentration slightly increases in most of the western Arctic except in the Chukchi Sea and southwestern Beaufort Sea.

The simulated difference field (Fig. 8f) captures the basic feature of the observed one: less compact ice in the eastern Arctic and more compact ice in the western Arctic. The model predicts similar decrease in ice concentration in most of the eastern Arctic and increase in the Kara Sea, an area near New Siberian Island, and an area close to Spitzbergen and Franz Josef Land. However, the model predicts more compact ice in an area south of Franz Josef Land, whereas the satellite obser- 


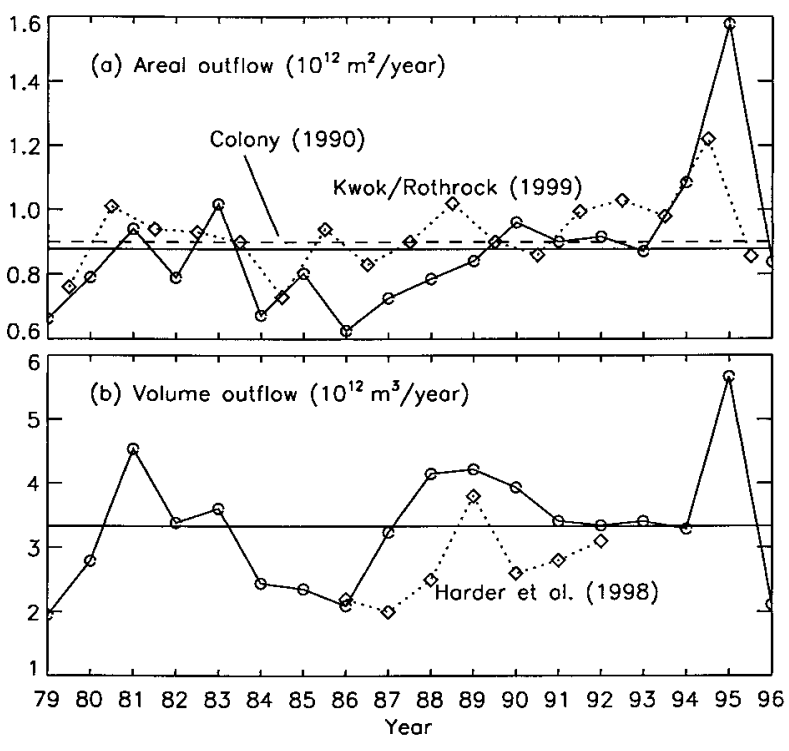

FIG. 7. (a) Annual ice areal outflow at Fram Strait simulated (solid line) by the model and derived (dotted line) by Kwok and Rothrock (1999) based on satellite passive microwave data, and an estimate (dashed line) by Colony (1990) based on buoy data. (b) Annual ice volume outflow at Fram Strait simulated by the model (solid line) and by Harder et al. (1998) (dotted line). The horizontal solid lines in (a) and (b) represent the simulated mean values for 1979-96.

vations show less compact ice. In the western Arctic, the model exaggerates ice compacting off the Alaskan and Canadian coasts in the Beaufort Sea, owing to an overprediction of ice concentration in 1989-96 and an underprediction in 1979-88 (Figs. 8b and 8d). Also, the model predicts decompacting in the Fram Strait area, whereas observations show compacting. Otherwise, the simulated increase in ice concentration in the western Arctic appears to be of the same magnitude as that observed.

The substantial reduction in ice concentration in the eastern Arctic during 1989-96 is further illustrated in Fig. 9a, whereas the changes in ice extent in the western Arctic are not as large (Fig. 9b). In the whole Arctic, both model results and observations also show a significant reduction in ice extent in recent years, in line with several previous studies (Gloersen and Campbell 1991; Chapman and Walsh 1993; Johannessen et al. 1995; Cavalieri et al. 1997). The pattern of the recent reduction in ice extent in the whole Arctic closely resembles that in the eastern Arctic, indicating that much of the recent reduction in ice extent in the whole Arctic is due to a reduction in the eastern Arctic.

\section{c. Recent changes in ice thickness: Eastern versus western Arctic}

The simulated fields of mean ice thickness for 197988 and 1989-96 are shown in Fig. 10. The general pattern for both periods is very thick ice off the Canadian Archipelago and North Greenland coast and thinner ice
TABLE 1 . Ice areal $\left(10^{12} \mathrm{~m}^{2} \mathrm{yr}^{-1}\right)$ and volume $\left(10^{12} \mathrm{~m}^{3} \mathrm{yr}^{-1}\right)$ outflows at Fram Strait.

\begin{tabular}{lcccc}
\hline \hline & $\begin{array}{c}1979-88 \\
\text { mean } \\
\text { (a) }\end{array}$ & $\begin{array}{c}1989-96 \\
\text { mean } \\
\text { (b) }\end{array}$ & (b) - (a) $[(\mathrm{b})-(\mathrm{a})] /(\mathrm{a})$ \\
\hline Areal outflow & 0.8 & 1.0 & 0.2 & $25 \%$ \\
Volume outflow & 3.0 & 3.7 & 0.7 & $23 \%$ \\
\hline
\end{tabular}

in the eastern Arctic. This agrees with the pattern observed by Bourke and McLaren (1992). However, there are considerable differences between the two fields. Notably, the ice is predicted to pile up in the east Siberian Sea in 1979-88, leading to thicker ice in the eastern Arctic. In contrast, the ice is thicker along the coasts of Alaska, Canada, and Greenland in 1989-96, leading to thicker ice in most of the western Arctic.

The differences are further illustrated in Fig. 10c, which shows the difference field of the simulated ice thickness. The spatial pattern is basically the same as that of the simulated ice concentration in Fig. 8f, reflecting a close spatial and temporal correlation between the modeled ice thickness and concentration. Since the large difference in the simulated ice concentration in the area off the Alaskan coast (Fig. 8f) is deemed unrealistic, compared with the observed difference (Fig. $8 \mathrm{e})$, we expect that the large difference in the simulated ice thickness in that area is also unrealistic, owing either to an underestimation of ice thickness in 1979-88 or to an overestimation in 1989-96, or both. Otherwise, the spatial pattern of the difference field of the simulated ice thickness in Fig. 10c reasonably matches that of the observed ice concentration in Fig 8e, both of which are dipolar. Collectively, the model results and satellite observations show that the Arctic ice cover lately has become significantly thinner and less compact in the eastern Arctic and somewhat thicker and more compact in a large area in the western Arctic.

The recent changes in ice thickness are further exhibited in Fig. 11. As shown in Fig. 11a, the simulated ice volumes in both regions are rather close before 1989 with a slight upward trend. Starting in 1989, the ice volume in the eastern Arctic drops sharply and has remained much lower ever since; in contrast, the ice volume in the western Arctic climbs a little further and has remained modestly higher ever since. On an annual average, the ice volume is reduced by $3.3 \times 10^{12} \mathrm{~m}^{3}$, or $28 \%$, in the eastern Arctic and is increased by $1.9 \times 10^{12} \mathrm{~m}^{3}$, or $16 \%$, in the western Arctic in 1989-96 (Table 2). This indicates that the dipolar pattern is not evenly formed because the decrease in ice mass in the eastern Arctic outpaces the increase in the western Arctic. As a result, the ice volume in the whole Arctic decreases in 1989-96 (Fig. 11c, solid line), down $1.4 \times 10^{12} \mathrm{~m}^{3}$, or $6 \%$ (Table 2), which is in line with the recent observations of a thinning Arctic sea ice cover (e.g., Rothrock et al. 1999).

The uneven dipolar pattern of the Arctic ice mass in the period of high-NAO/AO index is what we call the 


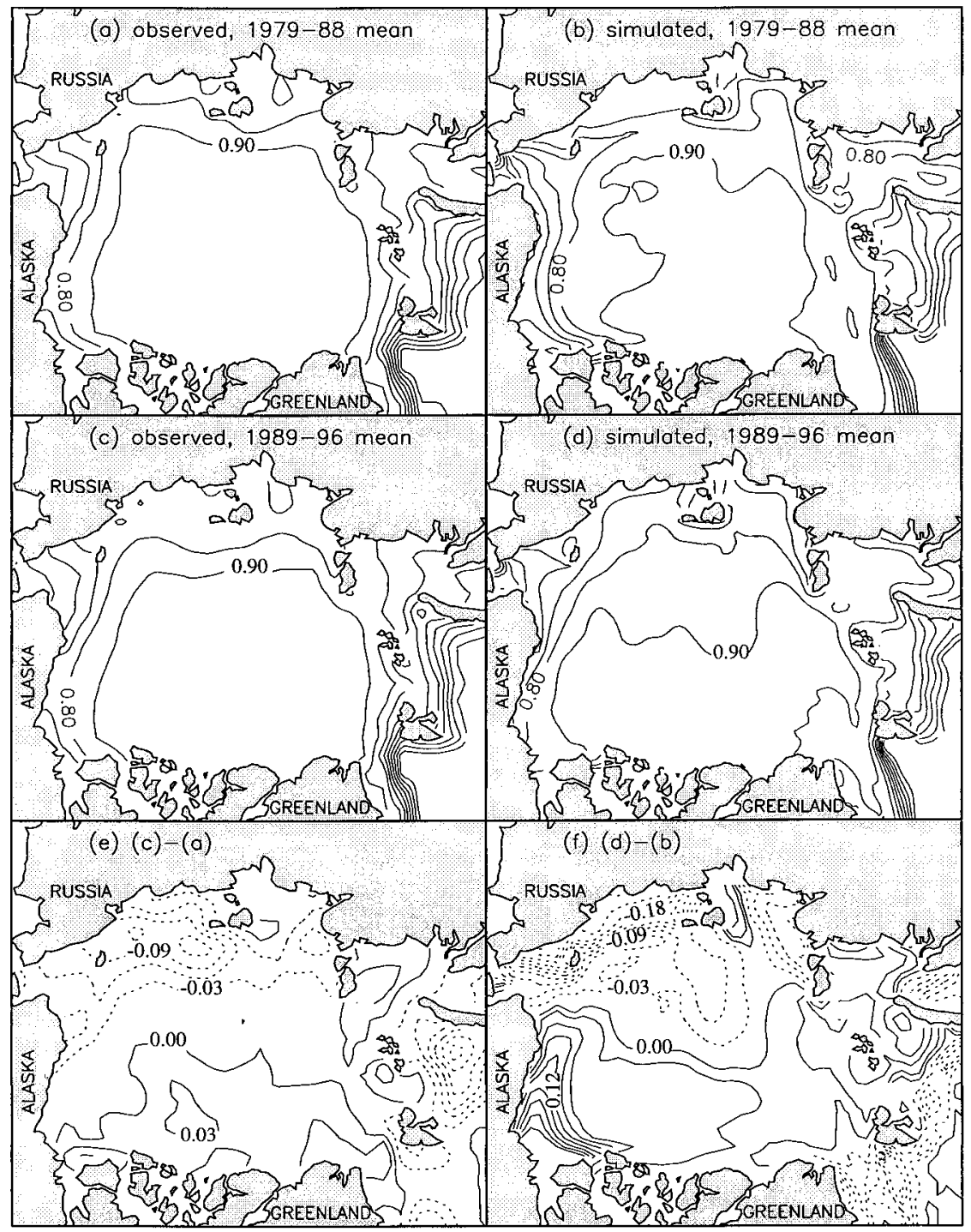

FIG. 8. Mean ice concentration (in fractions) fields observed by satellite sensors (the Scanning Multichannel Microwave Radiometer and the Special Sensor Microwave/Imager) and simulated by the model. (a) observed mean for 1979-88, (b) simulated mean for 1979-88, (c) observed mean for 1989-96, (d) simulated mean for 1989-96, (e) difference between observed mean for 1989-96 and observed mean for 1979-88, and (f) difference between simulated mean for 198996 and simulated mean for 1979-88. Contour interval is 0.1 for (a)-(d) and 0.03 for (e)-(f). The satellite data were provided by the National Snow and Ice Data Center.

East-West Arctic Anomaly Pattern (EWAAP). Spatially, it is reflected in the anomaly fields of ice concentration and thickness (Figs. 8e,f and 10c). As shown in the following sections, EWAAP is linked to the changes in ice motion (reflected in the anomaly ice motion fields in Figs. 6c and 6d) in response to the changes in winds (Fig. 4). It is also linked to changes in thermodynamic processes, such as growth and lateral melting.

\section{d. The effect of ice motion on ice thickness}

What causes EWAAP, that is, why is the eastern Arctic subject to a significant loss of ice and at the same time the western Arctic to a modest gain? One may attribute it to the spatially and temporally varying surface air temperature (Fig. 5), which determines the surface thermal forcing of the model. Of course, changes in thermal forcing result in changes in ice mass. This is shown in Fig. 11c where the simulated ice volume of the whole Arctic from a sensitivity study (the dotted line marked by "constant annual thermal cycle") is included. In the sensitivity study, the thermal forcing to drive the model uses 18-yr (1979-96) mean daily varying fields of surface air temperature, downward longwave and shortwave radiations, and specific humidity, while the wind forcing remains unchanged. The non- 

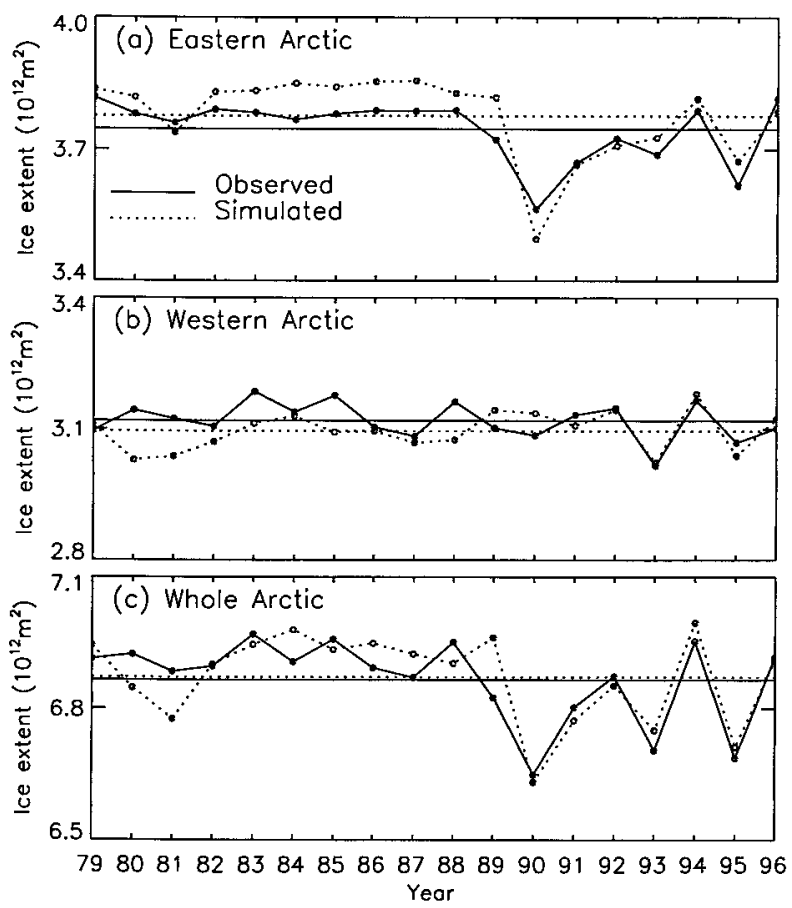

FIG. 9. Annual mean ice extent observed by satellite and simulated by the model for (a) the eastern Arctic, (b) the western Arctic, and (c) the whole Arctic. Ice edge is defined as a concentration of 0.15 . Note that the vertical range is the same in all three panels, $0.6 \times$ $10^{12} \mathrm{~m}^{2}$. The horizontal lines represent $1979-96$ mean values.

negligible difference between the ice volumes of the whole Arctic from the sensitivity study and the regular model with standard thermal and wind forcing suggests that changes in thermodynamics do affect ice mass (Fig. 11c). However, since the sensitivity study does not contain any interannual variability of thermal forcing, it reveals that the increase of ice volume before 1987, the peaking in 1987, and the decease after 1987 are all attributed to the interannual variability of wind forcing. Furthermore, the behavior of the simulated ice volume variations in the two regions basically does not change under the constant annual cycle of thermal forcing (Fig. 11b). This means that EWAAP has more to do with the interannual variability of the wind forcing and less to do with that of the thermal forcing. In other words, ice dynamics, mainly driven by winds, plays a dominant role in the spatial and temporal changes of Arctic sea ice over the last two decades.

How does ice dynamics affect the ice mass distributions in the two Arctic regions? We believe the answer lies in the function of the anticyclonic ice gyre (Fig. 6). One "branch" of the gyre appears to advect ice from the western Arctic into the eastern Arctic, and the other branch from the eastern Arctic into the western Arctic. Since the ice is generally thicker in the western Arctic and thinner in the eastern Arctic (Fig. 10), we expect that how the western Arctic ice is advected has a larger impact on the spatial distribution of ice mass in the

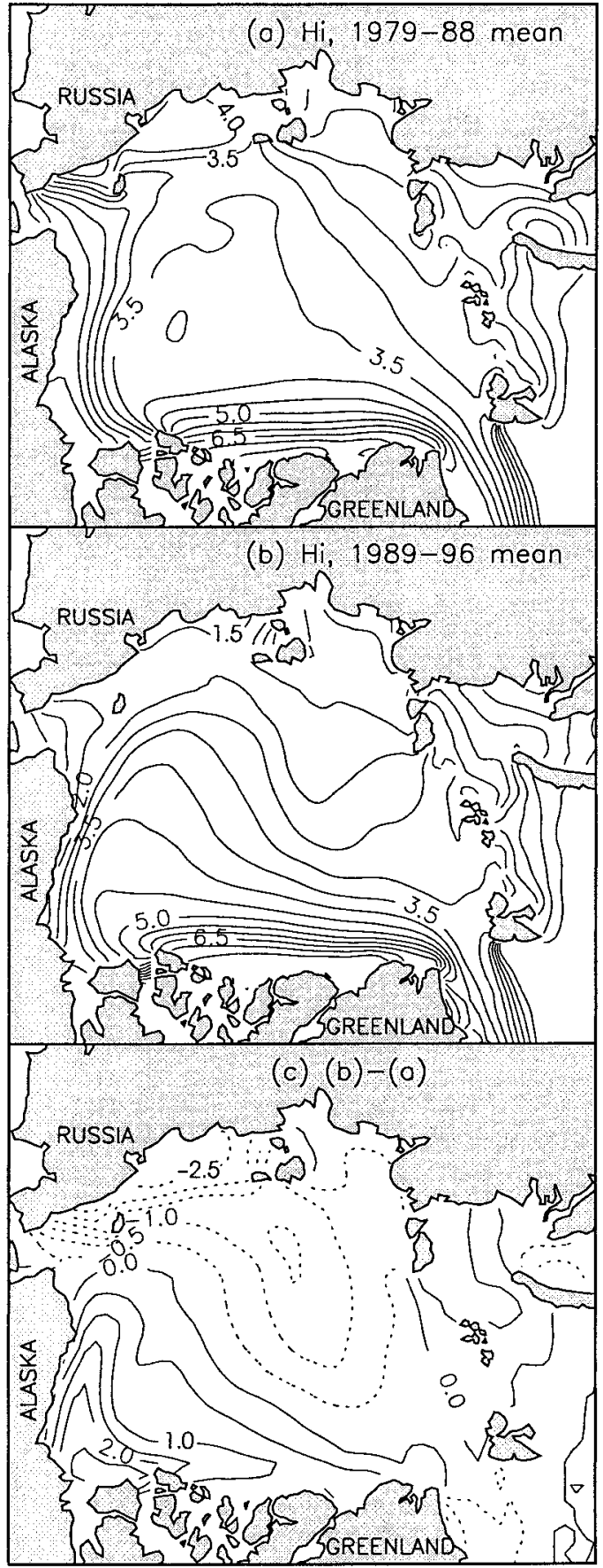

FIG. 10. Simulated mean ice thickness fields for (a) 1979-88 and (b) 1989-96 and (c) their difference field. Contour interval is $0.5 \mathrm{~m}$.

Arctic than how the eastern Arctic ice is advected. In 1979-88, the enhanced anticyclonic ice motion, driven by a stronger anticyclonic wind circulation, advects more thick ice in the Canadian Basin into the eastern Arctic and piles up ice to some extent along the coast of eastern Siberia. In 1989-96, in contrast, the weakened anticyclonic ice motion, driven by a weaker an- 

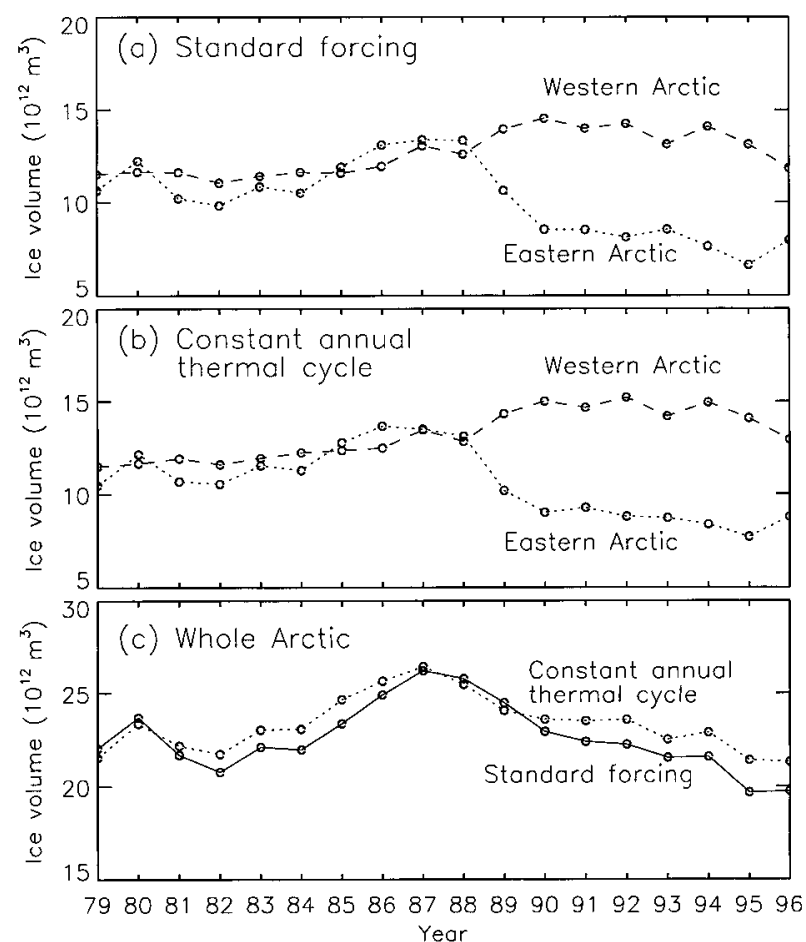

FIG. 11. Simulated annual mean ice volume in the eastern, western, and whole Arctic.

ticyclonic wind circulation, advects less thick ice into the eastern Siberian Sea. As a result, the whole eastern Arctic receives less thick ice and the western Arctic retains more ice in that period. This means that EWAAP is closely linked to the recent changes in ice dynamics in the period of high NAO/AO.

To understand further the effect of ice advection, represented by the first term on the right-hand side of (3), on ice mass, we define and calculate the amount of ice that advects into the eastern Arctic from the western Arctic across the transect $\overline{\mathrm{AB}}$ (marked in Fig. 2) along the prime meridian in the Chukchi Sea and Canadian Basin. Roughly speaking, this particular ice advection mainly comes from the action of the branch of the anticyclonic ice gyre (Fig. 6) that moves the generally thicker ice in the western Arctic into the eastern Arctic. Thus, the strength of this ice advection is to a large degree linked to that of the ice gyre. Of course, it is also linked to the ice thickness in that area. Note that the transect $\overline{\mathrm{AB}}$ is defined in a somehow arbitrary manner, but the link between the ice gyre and the ice advection across a moderately changed transect should not change qualitatively. The "west-to-east" ice advection across $\overline{\mathrm{AB}}$ (Fig. 12a) proves able to supply an enormous amount of ice to the eastern Arctic in 1979-88. In agreement with the study of Maslanik et al. (1998), however, this supply has been subject to a steep drop in recent years, reflecting reduced anticyclonic ice motion in response to the weakened Beaufort high and changed wind pattern in the Arctic. This is an indication that changes
TABLE 2. Ice volume $\left(10^{12} \mathrm{~m}^{3}\right)$.

\begin{tabular}{lcccc}
\hline \hline & $\begin{array}{c}1979-88 \\
\text { mean } \\
\text { (a) }\end{array}$ & $\begin{array}{c}1989-96 \\
\text { mean } \\
\text { (b) }\end{array}$ & (b) - (a) & {$[(\mathrm{b})-(\mathrm{a})] /(\mathrm{a})$} \\
\hline Eastern Arctic & 11.6 & 8.3 & -3.3 & $-28 \%$ \\
Western Arctic & 11.7 & 13.6 & 1.9 & $16 \%$ \\
Whole Arctic & 23.3 & 21.9 & -1.4 & $-6 \%$ \\
\hline
\end{tabular}

in the strength of the ice advection across $\overline{\mathrm{AB}}$ may serve as one of the important indicators of changes in ice motion and, hence, in the Arctic climate.

It is intuitive that the slump in the ice advection across $\overline{\mathrm{AB}}$ contributes to the loss of ice in the eastern Arctic and the gain in the western Arctic in 1989-96. We want, however, a quantitative analysis. Note that the ice motion over a large area of the Arctic consists of an ice gyre. We expect that a change in the ice advection across $\overline{\mathrm{AB}}$ would affect the total ice advection into the two regions. By total ice advection into either of the two regions, we mean the ice that comes into it through all of its open boundaries (see Fig. 2 for definitions of the open boundaries). The simulated total ice advection into the two regions is plotted in Fig. 12b, which is mostly negative because of a large ice volume outflow, mainly
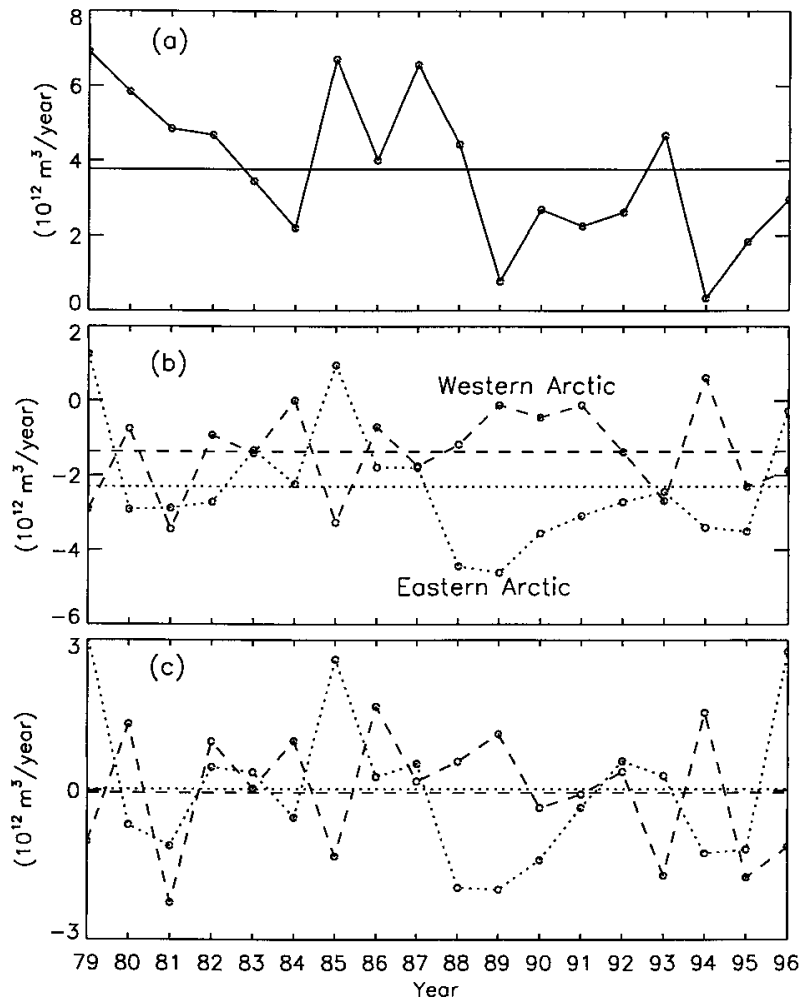

FIG. 12. (a) Simulated annual mean ice advection across transect $\overline{\mathrm{AB}}$ (marked in Fig. 2). (b) Simulated annual mean ice advection into the eastern or the western Arctic. (c) Simulated annual changes in ice volume for the eastern and the western Arctic. The horizontal lines represent 1979-96 mean values. 
TABLE 3. Correlations among simulated annual mean ice advection across transect $\overline{\mathrm{AB}}$ and ice advection into, ice volume change, and ice volume in the eastern and western Arctic. The numbers in the diagonal cells (underlined) are correlations between the eastern and western Arctic. The numbers in the cells above and below the diagonal cells are correlations between the different quantities for the eastern and western Arctic, respectively.

\begin{tabular}{l|c|c|c|c}
\hline \hline Western Arctic & $\begin{array}{c}\text { Ice advection } \\
\text { across } \overline{\mathrm{AB}}\end{array}$ & $\begin{array}{c}\text { Ice advection } \\
\text { into }\end{array}$ & $\begin{array}{c}\text { Ice volume } \\
\text { change }\end{array}$ & Ice volume \\
\hline Ice advection across $\overline{\mathrm{AB}}$ & & 0.60 & & \\
\hline Ice advection into & -0.66 & -0.55 & 0.95 & \\
\hline Ice volume change & & 0.84 & $\underline{-0.33}$ & \\
\hline Ice volume & & & & $\underline{-0.45}$ \\
\hline
\end{tabular}

at Fram Strait (Fig. 7b). The ice advection into the two regions is reasonably well correlated with the ice advection across $\overline{\mathrm{AB}}$, with correlations at or above 0.60 in magnitude as listed in Table 3. Thus, when the west to east ice advection across $\overline{\mathrm{AB}}$ drops from $5.0 \times 10^{12}$ $\mathrm{m}^{3} \mathrm{yr}^{-1}$ in $1979-88$ to $2.3 \times 10^{12} \mathrm{~m}^{3} \mathrm{yr}^{-1}$ in $1989-96$, the total ice advection into the eastern Arctic drops, too, from $-1.8 \times 10^{12} \mathrm{~m}^{3} \mathrm{yr}^{-1}$ in $1979-88$ to $-2.9 \times 10^{12}$ $\mathrm{m}^{3} \mathrm{yr}^{-1}$ in 1989-96. Meanwhile, ice advection into the western Arctic increases, from $-1.6 \times 10^{12} \mathrm{~m}^{3} \mathrm{yr}^{-1}$ in $1979-88$ to $-1.0 \times 10^{12} \mathrm{~m}^{3} \mathrm{yr}^{-1}$ in $1989-96$. This indicates that the ice advection across $\overline{\mathrm{AB}}$, driven by the anticyclonic ice gyre, significantly affects ice advection into the two regions.

The ice advection into the two regions, in turn, is highly correlated with changes in ice volume. The changes in annual ice volume are plotted in Fig. 12c, and the correlations, 0.95 for the eastern Arctic and 0.84 for the western Arctic, are listed in Table 3. They enforce the notion that changes in ice mass in the two regions are closely related to those in ice advection and, hence, in ice motion.

Previous model studies (e.g., Hibler 1984; Arbetter et al. 1997) demonstrate that the inclusion of ice dynamics in a sea-ice model tends to reduce the sensitivity of the modeled ice thickness to atmospheric warming or cooling in the polar oceans. In addition, Hibler and Zhang (1995) found that inclusion of ice dynamics in an idealized Atlantic ice-ocean model reduces the magnitude of oscillations in ice extent and thickness and in oceanic thermohaline circulation. Here, we have identified another facet of the effect of ice dynamics on ice thickness: ice dynamics tend to increase the variability of ice thickness in the two Arctic regions by changing how ice mass is advected, in response to the recent changes in Arctic atmospheric circulation. We want to stress the difference between the two sides of the dynamical effect. One is related to thermodynamic processes that affect ice thickness; the other is related to the physical distribution of ice mass in a two-dimensional space.

Finally, we want to examine the correlations (Table 3) between ice advection (Fig. 12b), between ice volume changes (Fig. 12c), and between ice volumes (Fig. 11) in the two regions. They are $-0.55,-0.33$, and -0.45 , respectively. These correlations are not high. Nevertheless, they enforce the notion that there generally exists a dipolar pattern in ice mass between the eastern and the western Arctic (also see Figs. 8e,f and 10c). That is, the eastern Arctic is likely to lose ice and the western Arctic to gain ice when the anticyclonic ice motion is weak and west to east ice advection is down in the period of high-NAO/AO index, leading to EWAAP.

\section{e. Recent changes in ice growth and lateral melting}

So far, efforts have been made to link the observed and simulated changes in the Arctic ice cover to those in ice advection that is controlled by ice dynamics. However, the ice-ocean system under consideration is a coupled dynamic-thermodynamic system. Thermodynamics comes into play as well. As stated by (3), a change in ice thickness distribution is determined not just by ice advection alone, but by a combination of ice advection, growth, lateral melting, and ridging. Because ridging only transfers ice from one category to another locally, the other three together determine the budget of ice mass in the Arctic. In this section, we examine the behaviors of the thermodynamic processes of ice growth and lateral melting, which are described, respectively, by the second and fourth terms on the right-hand side of (3).

The simulated annual mean ice growth is shown in Fig. 13a. In the eastern Arctic, ice growth is up 25\% from 1979-88 to 1989-96 (Table 4). This is due to more open water and thin ice in 1989-96, which greatly stimulates ice growth because the annual ice growth over open water or thin ice is relatively large (Maykut 1982). As mentioned before, the increased coverage of open water or thin ice, in turn, is largely due to a weakened ice gyre that advects less ice to the eastern Arctic from the western Arctic. This leads to a substantially increased ice growth even though the air is warmer (section 3). In the western Arctic, in contrast, ice growth is down $25 \%$ from 1979-88 to 1989-96 (Table 4). This is due to less open water and thin ice in 1989-96, which suppresses ice growth.

The ice growth is reasonably well (negatively) correlated with ice advection into the two regions, as shown in Table 5. That is, when advection delivers less ice to the eastern Arctic from the western Arctic, more ice grows in the eastern Arctic and less in the western Arctic. This appears to establish a negative feedback of ice growth to ice advection. Because of such a negative feedback, ice growth tends to restrain the changes in ice mass brought about by ice motion, and extreme ice conditions, such as an ice-free eastern Arctic, are not likely to occur unless the Arctic winter is extremely warm.

As pointed out before, some earlier studies have shown that ice dynamics reduces the sensitivity of ice 

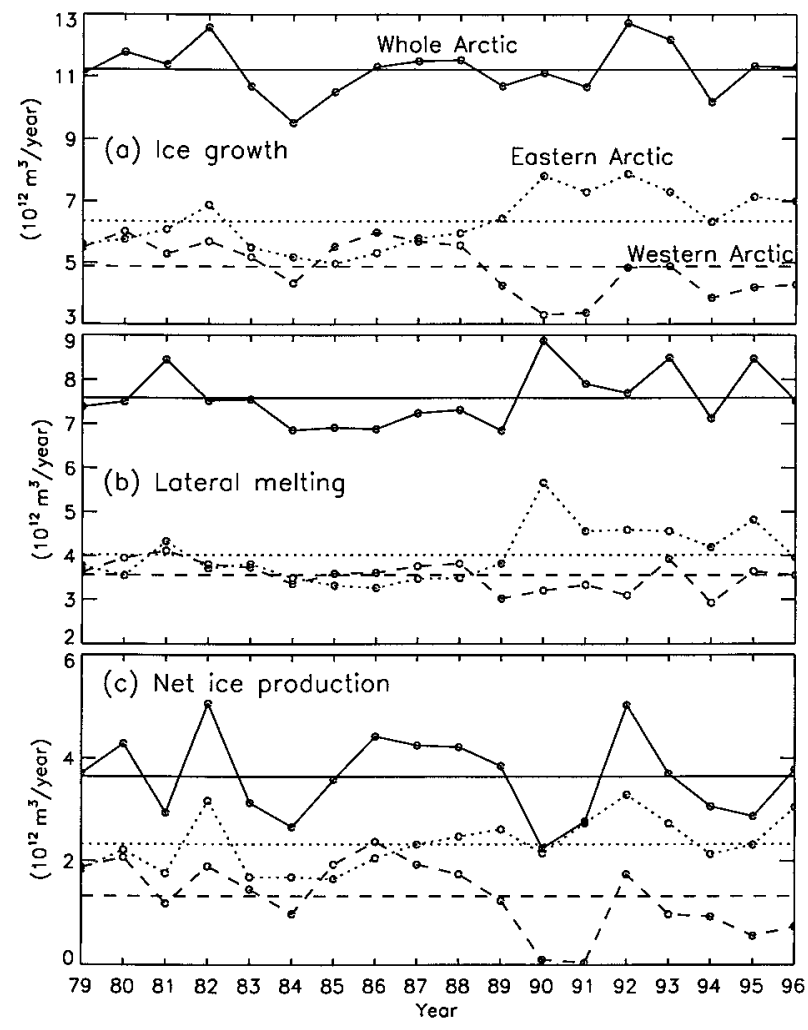

FIG. 13. Simulated annual mean (a) ice growth, (b) lateral melting, and (c) net ice production, defined as ice growth minus lateral melting, for the eastern, western, and whole Arctic. The horizontal lines represent 1979-96 mean values.

thickness to thermodynamical perturbations (e.g., Hibler 1984; Arbetter et al. 1997). Here, we have demonstrated that thermodynamic ice growth tends to reduce the sensitivity of ice thickness to dynamical perturbations (changes in ice advection). The roles of ice advection and ice growth appear to be complementary and represent an interplay between ice dynamics and thermodynamics.

The simulated annual mean lateral melting is shown in Fig. 13b. As with ice growth, more lateral melting is predicted in the eastern Arctic and less in the western Arctic in 1989-96 than in 1979-88. Unlike ice growth, however, the increase in lateral melting in the eastern Arctic is considerably more than the decrease in the
TABLE 5. Correlations among annual mean ice growth, surface albedo, lateral melting, ice advection into the eastern and western Arctic, and ice advection across transect $\overline{\mathrm{AB}}$. The numbers in the cells above and below the diagonal line are the correlations for the eastern Arctic and the western Arctic, respectively.

\begin{tabular}{l|c|c|c|c|c}
\hline \hline \multicolumn{1}{c|}{ Eastern Arctic } & Ice growth & $\begin{array}{c}\text { Surface } \\
\text { albedo }\end{array}$ & $\begin{array}{c}\text { Lateral } \\
\text { melting }\end{array}$ & $\begin{array}{c}\text { Ice } \\
\text { advection } \\
\text { into }\end{array}$ & $\begin{array}{c}\text { Ice } \\
\text { advection } \\
\text { across } \overline{\mathrm{AB}}\end{array}$ \\
\hline Ice growth & & & & $-0.64^{*}$ & $-0.57^{*}$ \\
\hline Surface albedo & & -0.96 & $0.64^{*}$ & $0.64^{*}$ \\
\hline Lateral melting & & -0.79 & & $-0.65^{*}$ & $-0.43^{*}$ \\
\hline Ice advection into & -0.42 & 0.65 & -0.63 & & -0.66 \\
\hline Ice advection across $\overline{\mathrm{AB}}$ & 0.78 & -0.54 & 0.72 & 0.62 & \\
\hline
\end{tabular}

* Ice advection into the eastern Arctic or ice advection across $\overline{\mathrm{AB}}$ leads ice growth, surface albedo, and lateral melting by $1 \mathrm{yr}$, indicating that the influence of ice advection at open boundaries of the eastern Arctic on the interior physical processes has about a $1-\mathrm{yr}$ phase lag. For the western Arctic, the correlations without a phase lag are slightly higher and are therefore used here because the western Arctic generally supplies ice to the eastern Arctic by advection.

western Arctic. In fact, lateral melting in the eastern Arctic is up 27\% during 1989-96, whereas that in the western Arctic is down only $11 \%$ (Table 4), which contributes to the formation of EWAAP with an uneven dipolar distribution of ice mass. As a result, the lateral melting in the whole Arctic is predicted to have a net increase of $8 \%$.

Net ice production, defined as the difference between ice growth and lateral melting, is shown in Fig 13c. The net production in the eastern Arctic is increased by $19 \%$ in 1989-96 because the increase in ice growth is larger than that in lateral melting (Table 4). However, this $19 \%$ increase is $6 \%$ less than the increase in ice growth because of the huge increase in lateral melting. The increase of $0.4 \times 10^{12} \mathrm{~m}^{3} \mathrm{yr}^{-1}$ in net production is three times smaller than the decrease of $1.2 \times 10^{12} \mathrm{~m}^{3} \mathrm{yr}^{-1}$ in ice advection into that region, indicating that ice dynamics plays a predominant role in the variability of ice mass in the eastern Arctic. This predominance is certainly linked to the action of the ice gyre that brings thicker ice from the western Arctic into the eastern Arctic.

In the western Arctic, the drop in ice growth in 198996 outpaces the drop in lateral melting, and the net production is considerably reduced, by $44 \%$ (Table 4 ). Because of the large decrease in net production in the

TABLE 4. Ice budget in the eastern (E), western (W), and whole Arctic (A) $\left(10^{12} \mathrm{~m}^{3} \mathrm{yr}^{-1}\right)$.

\begin{tabular}{|c|c|c|c|c|c|c|c|c|c|c|c|c|}
\hline & \multicolumn{3}{|c|}{ 1979-88 mean (a) } & \multicolumn{3}{|c|}{ 1989-96 mean (b) } & \multicolumn{3}{|c|}{ (b) - (a) } & \multicolumn{3}{|c|}{$[(b)-(a)] /(a)$ in $\%$} \\
\hline & $\mathrm{E}$ & $\mathrm{W}$ & A & $\mathrm{E}$ & $\mathrm{W}$ & A & $\mathrm{E}$ & $\mathrm{W}$ & A & $\mathrm{E}$ & $\mathrm{W}$ & A \\
\hline Ice growth (c) & 5.7 & 5.5 & 11.2 & 7.1 & 4.1 & 11.2 & 1.4 & -1.4 & 0.0 & 25 & -25 & 0 \\
\hline Lateral melting (d) & 3.6 & 3.7 & 7.3 & 4.6 & 3.3 & 7.9 & 1.0 & -0.4 & 0.6 & 27 & -11 & 8 \\
\hline Net ice production $=(\mathrm{c})-(\mathrm{d})$ & 2.1 & 1.8 & 3.9 & 2.5 & 0.8 & 3.3 & 0.4 & -1.0 & -0.6 & 19 & -44 & -15 \\
\hline Ice advection into* $(\mathrm{e})$ & -1.7 & -1.5 & -3.0 & -2.9 & -0.9 & -3.7 & -1.2 & 0.6 & -0.7 & 71 & -40 & 23 \\
\hline Net change in ice volume $=(\mathrm{c})-(\mathrm{d})+(\mathrm{e})$ & 0.4 & 0.3 & 0.9 & -0.4 & -0.1 & -0.4 & -0.8 & -0.4 & -1.3 & & & \\
\hline
\end{tabular}

* Ice advection into the whole Arctic is taken to be the negative ice outflow at the Fram Strait. 


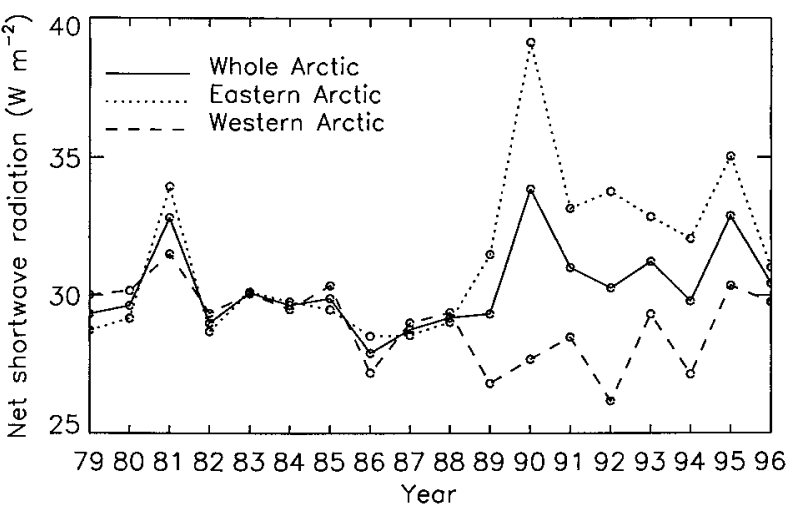

FIG. 14. Simulated annual mean net shortwave radiation at the surface.

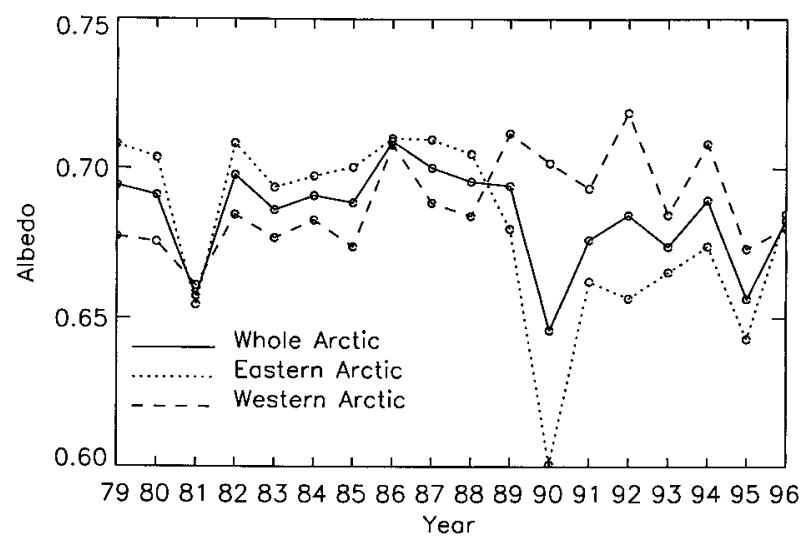

FIG. 15. Simulated annual mean surface albedo.

1980s, the air temperature is low, and the lateral melting is down, too; during 1989-96, the air temperature is up, and so is lateral melting. The correlation between these two is 0.68 . However, this correlation is not as high as that between the averaged lateral melting and the net surface shortwave radiation over the whole Arctic, which is 0.93 . This implies that surface solar heating plays a more prominent role in lateral melting.

The net surface shortwave radiation is plotted in Fig. 14. As with lateral melting, the surface solar radiation in the eastern and western Arctic starts to behave differently after 1988. In the eastern Arctic, the surface absorbs much more shortwave radiation than before owing to a substantially reduced surface albedo, as shown in Fig. 15. This intensified absorption of solar energy at the surface inevitably increases the heat penetration into the oceanic mixed layer through leads and therefore increases lateral melting. This, together with ice advection, contributes to a $28 \%$ decrease in ice volume during 1989-96. The correlation between lateral melting and surface albedo is as high as -0.96 (Table 5). In the western Arctic, the scenario is the opposite. The surface there absorbs less shortwave radiation owing to an increased surface albedo. As a result, lateral melting in the western Arctic is reduced, which contributes to an increase in ice volume, even though the air temperature is up by $0.4^{\circ} \mathrm{C}$. The correlation between the lateral melting and the surface albedo is -0.79 (Table 5). This correlation is not as high as its counterpart in the eastern Arctic, because the solar radiation is reduced and has less effect on lateral melting.

What causes the surface albedo feedback to behave differently in the two regions? We believe it is because of the varying ice advection. The evidence is given in Table 5, which shows that the lateral melting and surface albedo in both regions are reasonably well correlated with the ice advection into the two regions. They are also correlated to the ice advection across $\overline{\mathrm{AB}}$. In other words, the recent changes in surface albedo and lateral melting are closely related to those in ice advection. We know now that changes in the amount of ice advected (Fig. 5) and lateral melting (Fig. 13b) over the whole Arctic are reasonably well correlated. During the mid- 
TABLE 6. Surface albedo.

\begin{tabular}{lccc}
\hline \hline & $\begin{array}{c}1979-88 \\
\text { mean } \\
\text { (a) }\end{array}$ & $\begin{array}{c}1989-96 \\
\text { mean } \\
\text { (b) }\end{array}$ & (b) - (a) \\
\hline Eastern Arctic & 0.70 & 0.66 & -0.04 \\
Western Arctic & 0.68 & 0.70 & 0.02 \\
Whole Arctic & 0.68 & 0.66 & -0.02 \\
\hline
\end{tabular}

into the two regions are closely linked to those in the west to east ice advection across $\overline{\mathrm{AB}}$, which, in turn, are largely determined by changes in the anticyclonic ice motion driven by winds. Thus, we are able to attribute the recent weakening of the Beaufort high with triggering what we believe is a "chain reaction" that leads to different behaviors of the surface albedo in the two different Arctic regions.

In the eastern Arctic, the weaker winds during 198996 result in a weak anticyclonic ice motion/strong cyclonic ice motion anomaly; as a result, less ice is advected to the eastern Arctic from the Canadian Basin and Chukchi Sea, leading to a large area of thin ice and open water in the eastern Arctic. This large area of thin ice and open water in the eastern Arctic reduces the surface albedo and allows more absorption of downward shortwave radiation at the surface. More penetration of solar radiation causes more lateral melting. In the western Arctic, the chain reaction goes the other way. With less ice being advected from the west to the east, the ice sheet there becomes thicker and more compact. This increases the surface albedo and allows less absorption of shortwave radiation, leading to a decrease in lateral melting and an increase in ice volume. Obviously, such a chain reaction would not come to completion without ice advection being a key link.

Last, we point out that the reason the increase in lateral melting in the eastern Arctic is considerably greater than the decrease in the western Arctic in 198996 is because of the nonlinear effect of the positive surface albedo feedback. As shown in Table 6, the decrease in albedo in the eastern Arctic in that period is greater than the increase in the western Arctic. Because of the nonlinear effect, lateral melting tends to increase the dynamically induced variability of ice thickness, another interplay between ice dynamics and thermodynamics.

\section{Summary and concluding remarks}

We have coupled a multicategory thickness distribution sea-ice model to an ocean model with an embedded mixed layer and used the coupled model to study the behavior of the Arctic sea-ice cover in response to recent Arctic climate changes. Although the main feature of the simulated ice motion in the Arctic is consistently an anticyclone and a transpolar drift stream, the shape, strength, and location of the anticyclone and the transpolar drift stream vary considerably from
1979-88 to 1989-96 in response mainly to the changing winds. The anticyclone is weaker in 1989-96 than in 1979-88, leading to a substantial reduction in the west to east advection of ice across transect $\overline{\mathrm{AB}}$ along the prime meridian in the Chukchi Sea and Canadian Basin (Fig. 12a). The changes in the ice advection across $\overline{\mathrm{AB}}$ may serve as an indicator of those in the anticyclonic ice motion and hence in the Arctic climate. In contrast, the ice outflow at Fram Strait is 23\% stronger in 198996 than in 1979-88 (Table 1). The changes in ice outflow are also an indicator of changes in the Arctic climate.

Although the simulation shows a consistent pattern of thicker ice off the Canadian Archipelago and the northern Greenland coast and thinner ice in the eastern Arctic, the simulated thickness field averaged over 1989-96 is considerably different from that averaged over 1979-88. The thickness field shows a somewhat uneven dipolar pattern characterized by simultaneous thinning of ice in the eastern Arctic and thickening of ice in the western Arctic in 1989-96. The uneven dipolar behavior is a manifestation of what we call the East-West Arctic Anomaly Pattern, or EWAAP, which is closely linked to the changes in ice dynamic and thermodynamic processes in a high-NAO/AO period. From 1979-88 of lower-NAO/AO index to 1989-96 of high index, the simulated annual mean ice volume is reduced by $28 \%$ in the eastern Arctic and increased by $16 \%$ in the western Arctic, leading to an overall reduction of $6 \%$ over the whole Arctic. The uneven dipolar pattern is largely attributed to changes in lateral melting.

The simulated ice thickness appears to be closely correlated spatially and temporally with the simulated ice concentration. The recent reduction in ice concentration and thickness in most of the eastern Arctic and the increase in ice concentration and thickness in most of the western Arctic are directly linked to the recent changes in the amount of ice that advects into the two regions. The changes, in turn, are closely linked to those in the strength of ice advection across transect $\overline{\mathrm{AB}}$, which is controlled by the intensity of the anticyclonic ice gyre. When the ice motion is a strong anticyclone, more thick ice in the Canadian Basin tends to be advected into the eastern Arctic, leading to a gain of ice in the eastern Arctic and a loss in the western Arctic. When the ice motion is a weak anticyclone, which is the case during 1989-96, the west-to-east ice advection is greatly diminished, leading to less compact and thinner ice in the eastern Arctic and more compact and thicker ice in the western Arctic. All in all, the results emphasize the importance of ice dynamics by showing that, over the last two decades, the ice system reacts to climate variability not primarily through changes in thermal forcing, but through the changes in ice advection and the resulting distribution of mass.

The effect of ice dynamics on the variability of ice thickness in the eastern Arctic is particularly strong because the Beaufort ice gyre advects thicker ice in the 
western Arctic into the eastern Arctic. The dynamical effect is reduced in the western Arctic because the ice gyre advects thinner ice in the eastern Arctic into the western Arctic and therefore causes less variability of ice thickness.

Ice motion also affects ice thickness by influencing ice growth. The reduced ice advection into the eastern Arctic leads to more open water and thin ice in that region, which in turn leads to a substantial increase in ice growth. Meanwhile, it is also responsible for less open water and thin ice in the western Arctic, which leads to a decrease in ice growth. Thus, a negative feedback is established between ice growth and ice advection, in which ice growth stabilizes the dynamically induced variability of ice thickness, complementary to the dynamical effect that reduces the thermodynamically induced variability.

Ice motion also influences lateral melting in the two regions. Compared to those for 1979-88, the model results for 1989-96 show more lateral melting in the eastern Arctic, up 27\%, and less in the western Arctic, down $11 \%$. As a result, lateral melting in the whole Arctic has a net increase in 1989-96. This stresses the importance of lateral melting on the ice budget because the net increase of $0.6 \times 10^{12} \mathrm{~m}^{3} \mathrm{yr}^{-1}$ in lateral melting, together with the increase of $0.7 \times 10^{12} \mathrm{~m}^{3} \mathrm{yr}^{-1}$ in ice outflow at Fram Strait, is almost solely responsible for the prediction of an ice reduction of $1.4 \times 10^{12} \mathrm{~m}^{3} \mathrm{yr}^{-1}$, or 6\%, in the whole Arctic during 1989-96.

The influence of ice motion on lateral melting is closely linked to the effect of ice advection on surface albedo feedback. It fits into a chain reaction triggered by the recent changes in the Beaufort high. The recent weakening of the Beaufort high results in a weak anticyclonic ice circulation and a weak west-to-east ice advection, leading to an increase in open water and thin ice, a decrease in surface albedo, an increase in absorption of solar radiation at the surface, an increase in solar heating of the mixed layer, and an increase in lateral melting in the eastern Arctic. In the western Arctic, the chain reaction is the opposite, leading to a decrease in lateral melting.

However, the increase in lateral melting in the eastern Arctic is significantly greater than the decrease in the western Arctic because of the amplifying effect of surface albedo feedback. Because of that effect, lateral melting is destined to increase the dynamically induced variability of ice thickness, which is likely to contribute to the uneven dipolar pattern of ice mass (EWAAP) and a net loss of ice in the whole Arctic, in the event of significant climate changes, such as those recently observed. In such events, the eastern Arctic is probably most vulnerable, as far as ice mass is concerned, because of increased lateral melting as well as reduced west to east ice advection.

In summary, we have identified three mechanisms that influenced large-scale decadal change over the time period 1979-96.
1) Dynamics and spatial variability (section 4): We find that interannual changes in ice volume are forced primarily by ice dynamics. These changes result from spatial differences in the advection of ice within the Arctic Ocean. Specifically, we find that Arcticwide ice volume changes over the years 1979-96 derive largely from changes in the eastern longitudes.

2) Growth stabilization (section 5): Increasing (decreasing) open water leads to increasing (decreasing) ice growth. The result is a negative feedback on dynamically induced decadal changes in ice volume.

3) Dynamics and ice-albedo feedback (sections 5 and $6)$ : Increasing (decreasing) open water leads to increasing (decreasing) lateral melt. Dynamics preconditions the ice pack for ice-albedo feedback by its influence on the open water fraction. Specifically, we find enhanced (reduced) ice-albedo feedback in the eastern (western) Arctic during 1989-96 relative to $1979-88$, both forced by changes in ice advection. This feedback mechanism is largely responsible for an uneven dipolar pattern of ice mass distribution.

The model results and satellite observations all point to significant changes in the Arctic ice cover starting in 1987 in response to changes in atmospheric circulation. Will the changes in the ice cover deepen or vanish in the years to come? If they are an integral part of the $\mathrm{NAO}$ and the AO, which recently have high index, then they may vanish if NAO and AO completely reverse. Otherwise, the changes may persist or even deepen in the years to come, and the Arctic ice cover, particularly that in the eastern Arctic, may continue to shrink and may not swing back to its state prior to 1988 .

Acknowledgments. This work was supported by an EOS interdisciplinary Investigation, Polar Exchange at the Sea Surface (POLES), under NASA Grant NAGW 2407. We thank I. G. Rigor for providing sea level pressure and surface air temperature data, R. Kwok and H. Stern for their constructive comments, R. E. Moritz and I. G. Rigor for helpful discussions, and A. Schweiger and M. Ortmeyer for computer assistance. We also acknowledge W. D. Hibler III and G. M. Flato's valuable contributions to the early work on coupling the ice and ocean models.

\section{REFERENCES}

Arbetter, T. E., J. A. Curry, M. M. Holland, and J. A. Maslanik, 1997: Response of sea-ice models to perturbations in surface heat flux. Ann. Glaciol., 25, 193-197.

Bourke, R. H., and A. S. McLaren, 1992: Contour mapping of Arctic Basin ice draft and roughness parameters. J. Geophys. Res., 97, $17715-17728$.

Bryan, K., 1969: A numerical method for the study of the circulation of the world oceans. J. Comput. Phys., 4, 347-376.

Carmack, E. C., R. W. Macdonald, R. G. Perkin, F. A. McLaughlin, and R. J. Pearson, 1995: Evidence for warming of Atlantic Water in the Southern Canadian Basin of the Arctic Ocean: Results 
from the Larsen-93 Expedition. Geophys. Res. Lett., 22, 10611064.

Cavalieri, D. J., P. Gloersen, C. L. Parkinson, J. C. Comiso, and H. J. Zwally, 1997: Observed hemispheric asymmetry in global sea ice changes. Science, 278, 1104-1106.

Chapman, W. L., and J. E. Walsh, 1993: Recent variations of sea ice and air temperature in high latitudes. Bull. Amer. Meteor. Soc., 74, 33-47.

Colony, R., 1990: Seasonal mean ice motion in the Arctic Basin. Proc. Int. Conf. on the Role of the Polar Regions in Global Change, Fairbanks, AK, University of Alaska, 290.

Cox, M. D., 1984: A primitive equation, three-dimensional model of the oceans. GFDL Ocean Group Tech. Rep. 1, NOAA/Geophysical Fluid Dynamics Laboratory, 250 pp. [Available from NOAA/Geophysical Fluid Dynamics Laboratory, Princeton University, Princeton, NJ 08452.]

Flato, G. M., and W. D. Hibler III, 1995: Ridging and strength in modeling the thickness distribution of Arctic sea ice. J. Geophys. Res., 100, 18 611-18 626.

Gloersen, P., and W. J. Campbell, 1991: Recent variations in Arctic and Antarctic sea-ice covers. Nature, 352, 33-36.

Harder, M., P. Lemke, and M. Hilmer, 1998: Simulation of sea ice transport through Fram Strait: Natural variability and sensitivity to forcing. J. Geophys. Res., 103, 5595-5606.

Hibler, W. D., III, 1979: A dynamic thermodynamic sea ice model. J. Phys. Oceanogr., 9, 815-846.

- 1980: Modeling a variable thickness sea ice cover. Mon. Wea Rev., 108, 1943-1973.

- 1984: The role of sea ice dynamics in modeling $\mathrm{CO}_{2}$ increase Climate Processes and Climate Sensitivity, Geophys. Monogr., No. 29, Amer. Geophys. Union, 238-253.

— , and K. Bryan, 1987: A diagnostic ice-ocean model. J. Phys. Oceanogr., 17, 987-1015.

— an ice-ocean circulation model. Proc. NATO Advanced Research Workshop on Ice and Climate, Aussois, France, NATO, 633651.

$\longrightarrow$, and -1995 : On the effect of ice-dynamics on oceanic thermohaline circulation. Ann. Glaciol., 21, 361-368.

Hurrell, J. W., 1995: Decadal trends in the North Atlantic oscillation: Regional temperatures and precipitation. Science, 269, 676-679.

Johannessen, O. M., M. Miles, and E. Bjorgo, 1995: The Arctic's shrinking sea ice. Nature, 376, 126-127.

Kraus, E. B., and J. S. Turner, 1967: A one-dimensional model of the seasonal thermocline: II. The general theory and its consequences. Tellus, 19, 98-106.

Kwok, R., and D. A. Rothrock, 1999: Variability of Fram Strait Flux and North Atlantic oscillation. J. Geophys. Res., 104, 51775189.

Levitus, S., 1982: Climatological Atlas of the World Ocean. NOAA Prof. Paper 13, 173 pp.

Martin, S., and E. A. Munoz, 1997: Properties of the Arctic 2-meter air temperature field for 1979 to the present derived from a new gridded dataset. J. Climate, 10, 1428-1440.

Maslanik, J. A., M. C. Serreze, and R. G. Barry, 1996: Recent decreases in Arctic summer ice cover and linkages to atmospheric circulation anomalies. Geophys. Res. Lett., 23, 1677-1680.

—, C. Fowler, W. Emery, and J. Weatherly, 1998: On the interannual variability of Arctic sea ice transport: Relationships to atmospheric circulation modes and significance for GCM assessments. Proc. ACSYS Conf. on Polar Processes and Global Climate, WCRP-106, WMO/TD No. 908, Rosario, Orcas Island, WA, WMO, 156-158.

Maykut, G. A., 1982: Large-scale heat exchange and ice production in the Central Arctic. J. Geophys. Res., 87, 7971-7984.
McLaughlin, F. A., E. C. Carmack, R. W. Mcdonald, and J. K. B. Bishop, 1996: Physical and geochemical properties across the Atlantic/Pacific water mass front in the southern Canadian Basin. J. Geophys. Res., 101, 1183-1197.

Morison, J. H., M. Steele, and R. Anderson, 1998: Hydrography of the upper Arctic Ocean measured from the nuclear submarine USS Pargo. Deep-Sea Res., 45, 15-38.

Niiler, P. P., and E. B. Kraus, 1977: One-dimensional models of the upper ocean. Modelling and Prediction of the Upper Layers of the Ocean, E. B. Kraus, Ed., Pergamon Press, 143-172.

Parkinson, C. L., and W. M. Washington, 1979: A large-scale numerical model of sea ice. J. Geophys. Res., 84, 311-337.

Rigor, I. G., R. L. Colony, and S. Martin, 2000: Variations in surface air temperature observations in the Arctic, 1979-97. J. Climate, 13, 896-914.

Rothrock, D. A., Y. Yu, and G. A. Maykut, 1999: Thinning of the Arctic sea-ice cover. Geophys. Res. Lett., 26, 3469-3472.

Semtner, A. J., Jr., 1986: Finite-difference formulation of a world ocean model. Proceedings of the NATO Advanced Physical Oceanographic Numerical Modeling, J. O’Brien, Ed., D. Riedel, $187-202$.

Serreze, M. C., R. G. Barry, and A. S. McLaren, 1989: Seasonal variations in sea ice motion and effects on sea ice concentration in the Canada Basin. J. Geophys. Res., 94, $10955-10970$.

— J. J. E. Box, R. G. Barry, and J. E. Walsh, 1993: Characteristics of Arctic synoptic activity, 1952-1989. Meteor. Atmos. Phys., 51, 147-164.

— J. A. Maslanik, J. R. Key, R. F. Kokaly, and D. A. Robinson, 1995: Diagnosis of the record minimum in Arctic sea ice area during 1990 and associated snow cover extremes. Geophys. Res. Lett., 22, 2183-2186.

Steele, M., and T. Boyd, 1998: Retreat of the cold halocline layer in the Arctic Ocean. J. Geophys. Res., 103, 10 419-10 435.

_ J. Zhang, D. A. Rothrock, and H. Stern, 1997: The force balance of sea ice in a numerical model of the Arctic Ocean. J. Geophys. Res., 102, 21 061-21 079.

Thomas, D., 1999: The quality of sea ice velocity estimates. J. Geophys. Res., 104, 13 627-13 652.

Thompson, D. W. J., and J. M. Wallace, 1998: The Arctic oscillation signature in the wintertime geopotential height and temperature fields. Geophys. Res. Lett., 25, 1297-1300.

Thorndike, A. S., and R. Colony, 1982: Sea ice motion in response to geostrophic winds. J. Geophys. Res., 87, 5845-5852.

, - - and E. Munoz, 1983: Arctic Ocean buoy program. Data Report, Applied Physics Laboratory, University of Washington, 132 pp. [Available from Applied Physics Laboratory, University of Washington, 1013 NE 40th St., Seattle, WA 98105.]

Vowinckel, E., and S. Orvig, 1970: The climate of the North Polar Basin. Climates of the Polar Regions, S. Orvig, Ed., Vol. 14, World Survey of Climatology, Elsevier, 1-37.

Walsh, J. E., W. L. Chapman, and T. L. Shy, 1996: Recent decrease of sea level pressure in the central Arctic. J. Climate, 9, 480486.

Zhang, J., 1993: A high-resolution ice-ocean model with imbedded mixed layer. Ph.D. thesis, Dartmouth College, 229 pp. [Available from Dartmouth College, Hanover, NH 03755.]

— for modeling sea ice dynamics. J. Geophys. Res., 102, 86918702.

— D. A. Rothrock, and M. Steele, 1998a: Warming of the Arctic Ocean by a strengthened Atlantic inflow: Model results. Geophys. Res. Lett., 25, 1745-1748.

— W. D. Hibler III, M. Steele, and D. A. Rothrock, 1998b: Arctic ice-ocean modeling with and without climate restoring. J. Phys. Oceanogr., 28, 191-217. 